\title{
LOW DOSE KETOCONAZOLE THERAPY AND THYROID FUNCTIONS IN RATS
}

\author{
Hüseyin Çaksen ${ }^{1}$, Ahmet Tutuş ${ }^{2}$, Selim Kurtoğlu ${ }^{3}$, Figen Öztürk, Yüksel Okumuşs ${ }^{4}$, Bekir Çoksevim ${ }^{5}$ \\ Yüzüncü Yıl University, Van, Faculty of Medicine: Department of Pediatrics ${ }^{1}$; Erciyes University, Kayseri, Faculty of \\ Medicine: Department of Nuclear Medicine ${ }^{2}$, Department of Pediatrics ${ }^{3}$, Department of Pathology ${ }^{4}$, Department of \\ Physiology 5
}

Summary: To determine whether low dose ketoconazole (KTZ) has antithyroid action, we studied thyroid function tests in the 13 rats treated with KTZ (20 mg/kg twice daily) for thirty days. Serum triiodothyronine and thyroxine levels were decreased $(P<0.05)$ and serum thyroid-stimulating hormone levels were mildly increased $(P>0.05)$ at the end of treatment. Histopathological analysis of the thyroid glands demonstrated an increase in cylindrical cells in study group, but the epithelial cells were mainly cubical in control group. These findings showed that low dose KTZ had antithyroid effect in rats. The responsible mechanisms may be direct effect of the drug on thyroid gland.

Key words: Ketoconazole; Thyroid gland; Rat

\section{Introduction}

Ketoconazole (KTZ), a synthetic imidazole antifungal, is effective for superficial fungal infections, genital candidiasis and chronic mucocutaneous candidiasis, and has been used in immunocompromised patients and advanced prostatic carcinoma $(4,9)$. High doses of the drug, however, can exert an inhibitory effect of gonadal and adrenal steroidogenesis in vitro and in vivo. This endocrine effect can be rapidly reversed by interrupting the administration of the drug (14). Its chemical structure, comprising several heterocyclic rings and electron donor groups, indicated that KTZ may possess antithyroid activity (2). Namer et al (12) reported that some patients with high doses of KTZ (1200 $\mathrm{mg} / \mathrm{kg} /$ day) for breast cancer presented a biological hypothyroidism that required hormone replacement. Kitching (10) reported on two patients with severe mucocutaneous candidiasis and suggested that hypothyroidism might be a rare but not unlikely side-effect of KTZ therapy. In the previous study, we found that high dose of KTZ $(60 \mathrm{mg} / \mathrm{kg} /$ /day) had antithyroid effect in the rats (1). The purpose of this study was to determine whether low dose KTZ (20 $\mathrm{mg} / \mathrm{kg} /$ day) had antithyroid effect in-vivo.

\section{Material and Methods}

KTZ in powder form (Bilim Pharmaceuticals, Istanbul) was suspended in $0.3 \%$ Noble agar and administered orally to a group of 13 rats, twice daily ( $20 \mathrm{mg} / \mathrm{kg} / 0.1 \mathrm{ml} \mathrm{dose}$ ) at
$07^{00}$ and $17^{00} \mathrm{~h}$ for thirty days $(5,8)$. A control group received a placebo solution for thirty days. Twenty-six rats in two groups were included in this study. Control group; and study group; 13 rats treated with oral KTZ (20 mg/kg twice daily) for thirty days. Blood samples were drawn from the jugular vein to determine serum triiodothyronine $\left(\mathrm{T}_{3}\right)$, thyroxine $\left(\mathrm{T}_{4}\right)$ and thyroid-stimulating hormone (TSH) levels at the initial and on the $30^{\text {th }}$ day of therapy. At the initial the rats were weighed. At the end of the treatment period, the rats were killed and weighed. The body weights were compared with those of the controls. Thyroid glands were removed and weighed, and compared with those of the controls. Cross-section of thyroid glands was cut and examined histologically after suitable fixation and staining. A single cross-section (including both lobes) was evaluated for each animal and $>20$ follicles were measured by calculating the area enclosed by the apical surface of the follicular cells. The larger, more inactive, follicles along the periphery were excluded from the analysis. The activity of the gland was indicated by the appearance of the cells, and by the presence or absence of colloid. Hyperfunction was scored from + to ++++ as a function of the ratio of cylindrical to cubical cells $(2,3,13)$.

- = normal activity ( $<5 \%$ of cylindrical cells);

$+=$ moderate activity $(>5 \%$ to $\% 50$ of cylindrical cells);

$++=$ clear activity $(>50$ to $75 \%$ of cylindrical cells);

$+++=$ strong activity ( $>75$ to $90 \%$ of cylindrical cells);

$++++=$ extra-strong activity $(>90 \%$ of cylindrical cells). 
The concentrations of $T_{3}$ and $T_{4}$ in the serum were assayed using the radioimmunoassay (RIA) kit supplied by Diagnostic Products Corporation (Los Angeles, USA) and rat TSH with the RIA kit supplied by Amerlite Diagnostics Ltd. (Amersham UK). Statistical analysis was performed by Mann-Whitney U - Wilcoxon Rank Sum W test.

\section{Results}

The body and the thyroid gland weights of the animals are shown in Table 1. There was no statistically significant difference in the body weight and thyroid gland weight between the control and study group. In histopathological analysis of the thyroid gland, the epithelium was mostly cubical cells in control animals. In study group, cylindrical cells were increased in analysis of the thyroid glands. The hypothyroid state of the rats treated with KTZ was indicated by hyperfunction of the thyroid gland as indicated by the presence of cylindrical thyrocytes. However, there was no significant difference between the two groups $(P>0.05)$. Serum $\mathrm{T}_{3}, \mathrm{~T}_{4}$, and TSH levels in the control group and on the $30^{\text {th }}$ day of therapy of study group are shown in Table 2 . Serum $\mathrm{T}_{3}$, and $\mathrm{T}_{4}$ levels on the $30^{\text {th }}$ day of therapy were decreased in study group compared with control group $(P<0.05)$. Serum TSH levels were mildly increased at the end of treatment; however, there was not a significant difference between the groups for serum TSH levels $(P>0.05)$. Serum thyroid hormone levels $\left(\mathrm{T}_{3}, \mathrm{~T}_{4}\right.$, and TSH) at the initial of therapy in the study group were as follows; $\mathrm{T}_{3}$ : $0.0833 \pm 0.0227 \mu \mathrm{g} / \mathrm{dl}(0.0462-0.1139 \mu \mathrm{g} / \mathrm{dl}), \mathrm{T}_{4}: 5.26 \pm$ $1.14 \mu \mathrm{g} / \mathrm{dl}(3.09-6.95 \mu \mathrm{g} / \mathrm{dl})$, and TSH $1.54 \pm 0.45$ $\mu \mathrm{U} / \mathrm{L}(0.99-2.42 \mu \mathrm{U} / \mathrm{L})$. There was not a statistically significant difference for serum $\mathrm{T}_{3}, \mathrm{~T}_{4}$ and $\mathrm{TSH}$ levels between the initial values of the therapy in the study group and control group $(P>0.05)$.

\section{Discussion}

The effects of KTZ on different endocrine systems such as testosterone synthesis and cortisol production have been reported in-vitro and in-vivo. However, there is little information available on its action on thyroid gland and thyroid cells. Kohan et al (11) reported that KTZ (1-50 $\mu \mathrm{mol} / \mathrm{l})$ slightly increased the basal iodide uptake but, at higher concentrations (75-100 $\mu \mathrm{mol} / 1)$, it sharply decreased iodide uptake below the basal levels. The present work is the first report of KTZ action in a normal rat thyroid cell line. De Pedrini et al $(6,7)$ studied the effect of KTZ on thyroid function in five patients with thyrotoxicosis, five patients with hypothyroidism and ten normal subjects treated with KTZ at high dose $(600 \mathrm{mg} /$ daily in three $200 \mathrm{mg}$ oral doses) for four weeks. They found no inhibitory effect on the synthesis of thyroid hormones and thyroid function and they did not detect any antithyroid activity after administration of KTZ to the hypothyroid patients and ten healthy subjects.
Tab. 1: The weights of body and thyroid gland of the rats.

\begin{tabular}{lcccc}
\hline & $\begin{array}{c}\text { First body } \\
\text { weight }(\mathrm{g}) \\
\mathrm{X} \pm \mathrm{SD}\end{array}$ & $\begin{array}{c}\text { Last body } \\
\text { weight }(\mathrm{g})\end{array}$ & $\mathrm{Z}$ & $P$ \\
& $\mathrm{X} \pm \mathrm{SD}$ & & \\
\hline Control group & $188.4 \pm 40.3$ & $184.6 \pm 30.5$ & 0.20 & $>0.05$ \\
Study group & $212.7 \pm 34.6$ & $206.9 \pm 33.3$ & 1.8 & $>0.05$ \\
\hline \multicolumn{5}{c}{ Thyroid weight * } \\
$\mathrm{X} \pm \mathrm{SD}$ \\
Control group & $10.66 \pm 1.60$ & -1.50 & $>0.05$ \\
Study group & $12.19 \pm 3.44$ & & \\
\hline
\end{tabular}

* mg/100 g body weight

Tab. 2: Serum $\mathrm{T}_{3}, \mathrm{~T}_{4}$ and $\mathrm{TSH}$ levels in the control group and on the $30^{\text {th }}$ day of therapy in the study group.

\begin{tabular}{lcccc}
\hline Parameters & $\begin{array}{c}\text { Control Group } \\
(\mathrm{n}: 13)\end{array}$ & $\begin{array}{c}\text { Study Group } \\
(\mathrm{n}: 13)\end{array}$ & $\mathrm{z}$ & $P$ \\
\hline $\mathrm{T} 3(\mu \mathrm{g} / \mathrm{dl})$ & & & & \\
$\mathrm{X} \pm \mathrm{SD}$ & $0.0721 \pm 0.0199$ & $0.0500 \pm 0.0149$ & -2.89 & 0.003 \\
$(\mathrm{~min}-\mathrm{max})$ & $(0.0312-0.1098)$ & $(0.0301-0.0837)$ & & \\
\hline $\mathrm{T} 4(\mu \mathrm{g} / \mathrm{dl})$ & & & & \\
$\mathrm{X} \pm \mathrm{SD}$ & $6.23 \pm 1.63$ & $3.31 \pm 0.53$ & -4.13 & 0.00001 \\
$(\min -\mathrm{max})$ & $(3.47-9.11)$ & $(2.50-4.17)$ & & \\
\hline $\mathrm{TSH}(\mu \mathrm{U} / \mathrm{L})$ & & & & \\
$\mathrm{X} \pm \mathrm{SD}$ & $1.28 \pm 0.41$ & $1.55 \pm 0.57$ & -1.07 & 0.281 \\
$(\min -m a x)$ & $(0.61-1.87)$ & $(0.88-2.71)$ & & \\
\hline
\end{tabular}

The normal ranges of T3, T4 and TSH levels were as follows;

T3 0.0204 -0.1447 $\mu \mathrm{g} / \mathrm{dl}$; T4 2.25-9.89 $\mu \mathrm{g} / \mathrm{dl}$; and TSH 0.25-2.05 $\mu \mathrm{U} / \mathrm{L}$.

In our study, there was mild decreased body weight and mild increased thyroid weight in the study group compared with control group. Comby et al (2) observed a fall in body weight with respect to controls, which may have been due to a loss of appetite induced by the drug, and they also observed thyroid weight increased, as in our study. Comby et al (2) suggested KTZ could inhibit 5'-desiodase, which is responsible for $T_{3}$ and $T_{4}$ des-iodation, so keeping $T_{4}$ levels higher than expected in the in-vivo study. Our previous and present studies showed that both high and low dose KTZ had antithyroid effect in the rats. The responsible mechanism may be direct effect of the drug on thyroid gland. Nonetheless, since it is well-known that the changes of total plasma can effect the capacity and affinity of plasma proteins for thyroid hormones and the food intake has a clear cut effect on conversion of $\mathrm{T}_{4}$ to $\mathrm{T}_{3}$, these factors may also responsible for our results.

The work has been carried out in Erciyes University Faculty of Medicine, Department of Pediatrics, Kayseri, Turkey

\section{References}

1. Çaksen H, Tutuş A, Kurtoğlu S, Öztürk F, Okumuş Y, Çoksevim B. Antithyroid action of ketoconazole in the male rat. Pharm Sci 1996;2:499-501. 
2. Comby F, Lagorce JF, Buweraud J, Raby C. Antithyroid action of ketoconazole: In-vitro studies and rat in-vivo studies. J Pharm Pharmacol 1994;46:50-3.

3. Comby F, Lagorce JF, Moulard T, Buxeraud J, Raby C. Sulfamides antibacteriens, antiparasitaries et antifongiques derives de l'imidazole: evaluation des effet antithyroidiens sur le rat. Vet Res 1993;24:316-26.

4. Daneshmend TK, Warnock DW. Clinical pharmacokinetics of ketoconazole. Clin Pharmacokinet 1988:14:13-34.

5. De Fernandez ED, Patino MM, Graybill JR, Tarbit MH. Treatment of cryptococcal menengitis in mice with fluconazole. J Antimicrob Chemother 1986 18:261-70.

6. De Pedrini P, Montemurro G, Tommaselli A, Costa C. No effect of ketoconazole on thyroid function of normal and thyrotoxic patients. Int J Tissue React 1988; $10: 189-92$

7. De Pedrini P, Tommaselli A, Montemurro G. No effect of ketoconazole on thyroid function of normal subjects and hypothyroid patients. Int J Clin Pharmacol Res 1988;8:485-8.

8. Graybill JR, Palou E, Ahrens J. Treatment of murine histoplasmosis with UK 49,858 (Fluconazole). Am Rev Respir Dis 1986;134:768-70.

9. Gupta AK, Sauder DN, Shear NH. Antifungal agents: An overview. Part I. J Am Acad Dermatol 1994;30:677-98.

10. Kitching NM. Hypothyroidism after treatment with ketoconazole. Brit Med J 1986;293:993-4.
11. Kohan SL, Guillen CE, Pardec EM, Junco M, Soto RJ, Sartorio GC. Effects of ketoconazole on the iodide uptake by FRTL-5 cells. Acta Endocrinol (Copenh) 1992;127:449-53.

12. Namer M, Khater R, Frenay M, Boublil JL. High dose of ketoconazole in the treatment of advanced breast cancer. Bull Cancer 1986;73:89.

13. Ness DK, Schantz SL, Moshtaghian J, Hansen LG. Effects of perinatal exposure to specific $\mathrm{PCB}$ congeners on thyroid hormone concentration and thyroid histology in the rat. Toxicol Let 1993;68:311-23.

14. Pont A, Graybill JR, Craven PC, Galgiani JN, Dismukes WE, Reitz RE, Stevens DA. High dose ketoconazole therapy and adrenal and testicular function in humans. Arch Intern Med 1984;144:2150-3.

Submitted May 2002.

Accepted November 2002.

Hüseyin Caksen, MD,

K. Karabekir C. Gölbașı 3. S.,

Erkam sitesi. B Blok No: 3/7. VAN/TURKEY e-mail: huseyincaksen@hotmail.com 